\title{
Ecology, Literature and Environmental Education
}

\author{
Christos A. Tsekos (Corresponding author) \\ Department of Environmental and Natural Resources Management \\ University of Western Greece, 30100, G. Seferi 2, Agrinio, Greece \\ E-mail: ctsekos@yahoo.gr
}

Evangelos A. Tsekos

Department of Primary Education

University of Ioannina, 45110, Ioannina, Greece

E-mail: e.tsekos@yahoo.com

Elena I. Christoforidou

Department of Early Childhood Care and Education

Technological Educational Institute of Epirus, 30100, Ioannina, Greece

E-mail: ctsekos@yahoo.gr

Received: February 14, 2012 Accepted: February 24, 2012 Online Published: May 15, 2012

doi:10.5539/ies.v5n3p187

URL: http://dx.doi.org/10.5539/ies.v5n3p187

\begin{abstract}
The first part of this article refers to the initial attempt to relate Nature to Literature since the age of Hellenistic Alexandria in Egypt. Alexandria was a metropolis of its time with a quite lively character of urban life. Influenced by that character Theocritus was the first to lay the foundations of what is defined as pastoral poetry. In the course of this article and after the significance of contemporary Literature of Ecology is appraised, the results of a research with regard to the excerpts of both prose and poetry cited in the primary school textbooks in Greece - will be presented. Finally, an educational method is proposed which, we premise, would attribute a more experiential character to Literature for Instruction purposes.
\end{abstract}

Keywords: Environmental education, Literature, Primary school textbooks, Environmental awareness, Experiential learning

\section{Introduction}

Pastoral poetry constitutes one of the first literary genres aiming at positioning the reader to close proximity to Nature. This poetic genre was established in Hellenistic Alexandria in an anything but incidental period. To elaborate, during the first half of the 3rd c. B.C. there starts to flourish in Egypt a very big, if compared to other cities of that time, urban center with everything that a life, more or less detached from the direct communication with more natural ways of life, may entail for its inhabitants. Philo of Alexandria (end of $1^{\text {st }}$ c. B.C - beginning of $1^{\text {st }}$ c. A.D) provides us with a piece of information indicative of the large population of Alexandria estimating that there were approximately one million Jews residing in Egypt and that two out of the five quarters of the city were Jewish (Lesky, 1964). Additionally, the fact that the population of Alexandria was not exclusively Greek should also be taken into consideration. Indicatively, according to Walbank Alexandria constituted “...a cosmopolitan agglomeration of people and the heart of the Ptolemaic administration, with a large population of Macedonians and other Greeks, Jews as well as native Egyptians....” (Walbank, 1981). The establishment of Pastoral Poetry by Theocritus is also corroborated by Hans-Joachim Gehrke, member of the Heidelberg Academy of Sciences, according to whom Theocritus, the pioneer of this new literary genre, along with the indubitable contribution of his successors presented Europe with "the artistic landscape of Arcadia" (Gehrke, 1991). Within this climate of "confinement" of the person into the narrow, as far as natural life is concerned, psychical limits of a city it was utterly rational for even an alleged gateway of communication with what was missing, that is a reconnection with Nature, to be zealously sought for. As Lesky denotes "firstly the city dweller had to realize the loss of Nature within 
the castles of the Hellenistic city so as later to succeed in generating something equal to Theocritus' Iddyls” (Lesky, 1964). As a result, the systematic cultivation of pastoral poetry was then inaugurated by Theocritus in Alexandria. The word systematic in this case signifies that even before Theocritus there are shreds of pastoral poetry to be found in Sicily and in Sparta (Bulloch, 1985).

Within the general atmosphere of the period (the age of the successors of Alexander the Great), which was characterized by intense social-military upheaval, and under the influence of psychological tension unavoidably provoked by civil life, it was quite natural for pastoral poetry to take shape since it would bring the reader closer to the life of the lost paradise of Nature among shepherds, fipple flutes, songs, blooming trees and flowers as well as breathtaking landscapes; images that would facilitate the respiration of the soul from the racket and the psychological suffocation of the city. This genre of poetry would eventually give the reader at least the illusion of returning to Nature and a sense of environmental awareness which to date seems to be lost within the walls of urban coexistence. After all, the fact that many a poets, such as Bion, Moschus, or Virgil emulated Theocritus even since the Alexandrian (Lesky, 1964) and the Roman imperial age (Albrecht, 1999) proves how much, on a psychological level, the detachment from the natural habitat has cost to humankind. Moreover, the expansion of the spiritual movement of Arcadianism in the European continent in the following years demonstrates nothing less than the desire of man to reunite with Nature. It is imperative at this point that we cite an excerpt from Theocritus' "Idylls" in which it is by means of the simplicity of the bucolic way of living that the beauty of living close to Nature emerges (Theocritus, 2003) .

\section{IDYLL VII. THE HARVEST-HOME}

[128] “...in deep greenbeds of fragrant reeds and fresh-cut vine-strippings laid us rejoicing down.”

[135] "Many as aspen, many an elm bowed and rustled overhead, and hard by, the hallowed water welled purling forth of a cave of the Nymphs, while the brown cricket chirped busily amid the shady leafage, and the tree-frog murmured aloof in the dense thornbrake. Lark and goldfinch sang and turtle moaned, and about he spring the bees hummed and hovered to and fro ... Pears lay at our feet, apples on either side, rolling abundantly, and the young branches lay splayed upon the ground because of the weight of their damsons."

Admittedly, in our time and age humankind is severely constricted in big urban centers on account of the absence of the natural environment. What is even worse, Nature itself suffers from so many maladies incidental to the irrational use of technology. Shouldn't we, therefore, be opting for ascribing a more active role to the ecological literature in education in order for environmental awareness to be shaped?

\section{Literature and Environmental Awareness Nowadays}

Literature, being one of the Fine Arts, serves not only in shaping personalities but in forming the social structures as well. As a form of Art, Literature holds this asset: whatever is provided by the other forms of theoretical life in a rationalized process, naturally degrading to becoming rather tiresome to the reader, is offered by Literature - and apparently Art in general- in a pleasing way through the enticement of the Fine and the expression of the Beauty. Paul Valéry wrote that: "Ruminations ought to be concealed within the lyrics of a poem as does the nutritional value in a fruit. A fruit is a form of nourishment but seems to be simply an indulgence. We simply feel the lust but at the same time we also receive an essence. It is Enchantment that veils the inconspicuous nourishment it boasts" (Papanoutsos, 1969). As it is commonly accepted, Literature usually resorts to describing Nature in an attempt to creatively depict - since admittedly the artist does not emulate but simply creates - Beauty. Both scholar and folk Literature "pattern" the beauty of Nature (the elemental form of Lyricism), thus giving the literature the opportunity to bring forth his/her creative ability.

On the other hand one of the most fundamental objectives of Social Studies is, as mentioned by Professor Houser, "to promote self-development and social understanding for the improvement of society at large". Additionally, according to him, since emotions are a fundamental element of human experience, the use of Literature - just as of other approaches based on Art - may contribute towards the realization of this objective (Houser, 2001).

At this point however, it should be mentioned that the success in raising environmental awareness along with the concomitant change in the children's conduct (a result not always achieved through the typical use of Environmental Education) through the reading of relevant books has already been demonstrated by different researches (Chawla, 1998 \& 1999; Tanner, 1980; Gardner and Stern, 1996). Moreover, another survey, conducted in secondary teachers, has shown that their reading books in class has contributed decisively in raising environmentally responsible students in comparison to the contribution of the TV and the newspapers (Hsu and Roth, 1998).

Moreover, the significance of environmental awareness, especially to youngsters, is worth being stressed since they are the future adult citizens to participate dynamically towards the conservation of the environment. To that 
direction, children's Ecological Literature may lead a contributory role (Kanatsouli, 2005). As O’ Brien and Stoner infer, children's books with a literary character are far more interesting to children than knowledge books and offer them a chance to acquire knowledge on different environmental concepts (O' Brien and Stoner, 1987). However, there are certain cases that the way in which the children are exposed to the concepts of the contemporary environmental problems is not the appropriate one. More specifically, one of the most unfortunate instances in the realm of children's Ecological Literature is when the authors tend to exaggerate so as to raise the children's awareness about current environmental issues thus ending up in presenting an alleged environmental inferno. Consequently, children feel hopeless and disempowered and a phobia, identified by Sobel as ecophobia, is developed (Sobel, 1996). And that can be far more serious if one considers, for example, the case of a 10-year-old pupil who described his exposure to some pictures depicting the destruction of the rainforests as rather scary (Pierce and Short, 1994) or that of Mc Knight stating that one day she saw her daughter crying, for fear of the Galapagos Islands becoming extinct (Mc Knight, 2010).

The purpose of the present article is twofold; firstly, to examine whether there are any prose passages or poems with environmental themes in the Anthologies of Literary Texts (the books used in Primary Education Schools for teaching Literature) and secondly, to examine the way in which these topics are presented.

\section{Research Method}

In order to examine, on the one hand, the presence of any prose passages and poems with ecological topics in the school textbooks and, on the other hand, the way in which they are presented, the technique of content analysis has been employed. This method has already been used by other researchers as well (Abimbola and Baba, 1996; Dikmenli, Cardak and Öztas, 2009). Therefore, we have come to a resolution to analyze two books namely the Anthologies of Literary texts addressed to $3^{\text {rd }}$ and $4^{\text {th }}$ (the first one) as well as $5^{\text {th }}$ and $6^{\text {th }}$ (the second one) class pupils of Primary Education respectively.

\section{Results and Analysis}

In order to ascertain the way in which the aforementioned textbooks of Primary Education deal with issues relative to Nature, Environment and Environmental Problems, an analysis in some of their contents (of both prose passages and poems) is to be undertaken. In the Anthology of Literary Texts for the $3^{\text {rd }}$ and $4^{\text {th }}$ graders there is a thematic unit of prose texts and poems entitled "Nature and Ecology" whereas in that for the $5^{\text {th }}$ and $6^{\text {th }}$ graders there is one entitled "We and the Nature".

Our analysis is to commence with a wonderful passage entitled "The fall of Freddie the leaf" written by Leo Buscaglia. It describes the life cycle of a leaf called Freddie. Freddie is presented as having human properties since it is capable of contemplating and feeling - for instance the moment of its fall on the ground - as if it were a human being. To our mind, in this text not only does the writer succeed in enacting to the reader the sensation that Freddie acts as humans do but manages to accent the value of a leaf's life, thus attributing a special ecocentric character to the text (Ecocentrism is a philosophical movement governed by the viewpoint that inherently it is not worth striving only for the preservation of the humans' well-being but for that of the other beings on our planet as well). As it has already been mentioned, the way in which the writer approaches the issue of the leaf's (Freddie's) life cycle and its natural final fall from the tree to the ground attempts to attribute to the leaves (and, by extension, to non-human beings too) thoughts, senses and feelings with the overall aim to stimulate to his young readers the feeling of empathy towards the rest forms of life (besides humans). Concurrently, he chooses not to dwell onto the vexing aspect of the fall as such but, reversely, tries to present the death of the leaf as a completely natural event, which will eventually give birth to a new form of life via the perpetual ecological cycles of the elements, to which the author indirectly refers.

To continue, in the texts "The whale's song” by Dyan Sheldon, "The silver Road" (O asimenios dromos) by Georgios Bondis, "The Caretta-Caretta turtle and the old Volkswagen" (I xelonitsa Caretta-Caretta kai to palio Volkswagen) by Christos Boulotis as well as on the previously cited text by Leo Buscaglia an attempt, on behalf of the authors, to assign human properties to the animals is prevalent. The first excerpt by Dyan Sheldon refers to a special relationship between a little girl - Lilly - and whales. Whales are portrayed as beings which can talk but sing too (as a reciprocation gesture) for Little Lilly when they are offered a flower by her. The same mentality governs the remaining texts which in an exquisite way attempt to introduce us to the internal world of the animals which are endowed with the ability to talk, think and feel as though they were humans. Moreover, in "The silver Road" by Georgios Bondis the central figure of the excerpt is a small porcupine, whose name is Porcupinos, who decides to travel to the city to dissuade humans from razing the forest. Finally, in his passage "The Caretta-Caretta turtle and the old Volkswagen" Christos Boulotis places the pivotal focus on a conversation between a small turtle and a car among whom a special form of friendship is developed. The car, being older, is trying to advise its little friend on 
the reigning inconsiderateness of humankind towards the other forms of life. In this ingenious way the writer indirectly communicates messages regarding the way in which the Caretta - Caretta turtle reproduces, as well as concerning the great hazard lurking for the newborn turtles to die and for the their eggs to be destroyed due to the way it spawns on the beach alongside with the mindlessness and indifference of people who are vacationing there.

Nonetheless, besides the excerpts which are portraying animals and plants as human beings, we consider that the largest part of the texts and the poems which have been selected for the textbooks under scrutiny as a whole mainly focus on lyrical images which celebrate Nature, its creatures and the grandeur of its beauty. The most representative of these are "The orange and a sunray" (To portokali kai mia iliaxtida) by Manos Kontoleon, "The community of the Lake" (I politia tis limnis) by I. M. Panagiotopoulos, "The astrolabe" (O astrolavos) by Fotis Kontoglou, "I asprouda" by Eleni Choreanthi, and the poems "Gazing at the sea" (Na se agnadevo thalassa) by Kostas Varnalis and "The sovereign sun" (O ilios o Iliatoras) by Odysseas Elytis.

We could say that an exception to the two previous categories is the excerpt "Emergency action on the smog in Lilipoupoli" (Ektakta metra sti Lilipoupoli gia to nefos) by Marianina Kriezi and Regina Kapetanaki as well as the poem "Persephone's nightmare" (O efialtis tis Persefonis) by Nikos Gatsos. Both these literary works constitute the only occurrences in the anthologies of Literary Texts in which the human factor with its behavior is to be held primarily responsible for the contemporary environmental problems, for example the smog. In the first passage, in an inspired way both writers refer not only to the smog, as being a major environmental problem of our time, and its direct ramifications to our health but also to the human hypocrisy and unconcern which more often than not is the primary cause of environmental problems. References to some of the contemporary environmental problems are also made in Nikos Gatsos' poem with distinct references to the cement, the cigarette ends and the shipyards (connoting to the unsystematic build and urban sprawl, the waste and sea pollution respectively). Unfortunately however, we can see that except for the passages of Kriezi and Kapetanaki and the poem by Nikos Gatsos there is no reference to any other major contemporary environmental issues (e.g. water scarcity, forest conservation, intense urbanization, species extinction) in no other parts of both Anthologies. For once more we can observe the notions of Environment and Ecology being identifying with the concept of Nature. Besides that, as is it is commonly accepted, the environment consists of the Natural and the Anthropogenic environment, which (the Anthropogenic), in turn, consists of the structured, the social, the historic and the cultural environment (Bortman et. al., 2003; Munn et.al., 2001; Tsekos and Matthopoulos, 2009)

\section{A proposal for Teaching}

Environmental Education is not a one-dimensional procedure as is the case of traditional education in which the educational asset is offered only by means of the "frontal" teaching. On the contrary, it possesses a three-dimensional character as it is internationally accepted (Palmer, 1998).

More specifically, Environmental Education is divided into three forms:

a. Environmental Education about the environment

b. Environmental Education in or from the environment

c. Environmental Education for the environment

This distinction is consistent both with the psychological data and more specifically the correspondence with the cognitive, emotional and ethical aspect of human personality and the pedagogical data since it accords with Bloom's tripartite taxonomy of the educational objectives into a cognitive, emotional and psychokinetic area (Skanavis, 2004). The first form of Environmental Education (which correlates with the cognitive hypostasis of the personality) attempts to transfer knowledge through teaching subjects which refer to the Environment on scientific fields related not only to Natural Sciences, e.g. Physics, Chemistry, Biology, Geology, but also to Social Sciences and Humanities, e.g. Economics and History. Additionally, the last one is based on the principle that environment is composed by the natural and the anthropogenic environment, as previously stated. The second form of Environmental Education appears through activities realized in the environment as such, where the participants can experience it, its value and its problems directly and personally by assuming activities within it. Last but not least, the third form is about our moral attitude towards the environment and it deals with shaping ecological values, attitudes and behaviors.

Not wanting to devaluate the other forms of Environmental Education we assert that a special emphasis should be placed upon the "in or from the Environment" form - the more experiential form of Environmental Education par excellence. That is mainly because whatever is experienced via direct and personal contact can be permanently acquired. Some of the methods applied by Environmental Education are the Problem Solving Method, the Project Method, the Field Trip, and The Environmental Trails Method (Dimitriou, 2009, Tamoutseli, 2011). A common and fundamental element of these methods is the involvement of the student with the environment and its problems 
based on the educational principle "learning by doing" advocated by J. Dewey, the basic representative of New Education. It is therefore obvious that experiential learning is by far the most effective way of learning in relation to learning via hearing or reading. Nevertheless, an allusion to the function of the last two methods should be made. To be more specific the "in or from the Environment" Environmental Education along with the Field Trip and The Environmental Trails methods may render the ecologically-oriented literature beneficial to shaping ecologically responsible behaviors. The readout of a literary text, its recitation and, if possible, the analysis of a work of Literature with an environmental topic within the natural environment - which is what we recommend, as far as the present article is concerned - will accredit another dimension to the communication and the approach of the text on behalf of the students, since any representation will not be coherently reproduced, any feelings and desires will not be created by means of coherent depiction but they will be functioning through the direct experience of reality.

\section{Concluding Remarks}

Since the Hellenistic period, humans have attempted to approach Nature and come into close contact with it by means of Art, in general, and Literature, in particular. After these facts have been taken into consideration, we render that the diachronic need of humankind to be closer to the natural habitat and to more natural lifestyles can easily become apparent. Nowadays, due to the extent and the intensity of environmental problems plaguing our planet, ecologically-oriented Literature has become a constantly developing field especially when it comes to Children's Literature. Notwithstanding the paramount importance of Ecological Literature (on account of its ability to foster environmental awareness from very young ages), the writers, in their attempt to move young readers, usually resort to employing exaggerations in their literary works thus generating the opposite result. Additionally, as far as the literary texts used in Greek Primary Education are concerned, it could be maintained that on the one hand, exaggerations - as the aforementioned - are avoided while praising the lyrical element of Nature and devaluating the humans' contribution- the basic cause causans- to current environmental issues prevail. To conclude, if Environmental Education aims at sensitizing the students on environmental issues and at helping them adopt an environmentally responsible behavior, a more active role should be attributed to it.

\section{References}

Abimbola, I.O., \& Baba, S. (1996). Misconceptions and alternative conceptions in science textbooks: the role of teachers as filters. The American Biology Teacher, 58(1), 14-19.

Albrecht, M.V. (1994). Geschichte der Römischen Literatur. München: K.G Saur Verlag.

Bortman, M., Brimblecombe, P., Cunningham, M.A., \& Cunningham, W.P. (Eds) (2003). Environmental Encyclopedia, 1, Michigan: Thomson Gale.

Bulloch, A.W. (1985). Hellenistic Poetry, In: P.E. Easterling and B.M.W Knox (Eds) The Cambridge History of Classical Literature I: Greek Literature (pp. 556-569). New York: Cambridge University Press.

Chawla, L. (1998). Significant life experiences revisited: a review of research on sources of environmental sensitivity. Journal of Environmental Education, 29, 11-21. http://dx.doi.org/00958969809599114

Chawla, L. (1999). Life paths into effective environmental education. Journal of Environmental Education, 31, 15-26. http://dx.doi.org/00958969909598628

Dikmenli, M., Cardak, O., \& Oztas, F. (2009). Conceptual Problems in Biology - Related Topics in Primary Science and Technology Textbooks in Turkey. International Journal of Environmental and Science Education, 4(4), 429-440.

Dimitriou, A. (2009). Environmental Education: Environment, Sustainability. Theoretical and pedagogical approaches. Thessaloniki: Epikentro.

Gardner, G.T., \& Stern, P.C. (1996). Environmental problems and human behavior. Boston: Allyn and Bacon.

Gehrke, H.J. (1991). Geschichte des Hellenismus. München: R. Oldenburg Verlag.

Houser, N. (2001). Literature as Art, Literature as Text: exploring the power and possibility of a critical, literacy-based approach to citizenship education. Equity and Excellence in Education, 34(2), 62-74. http://dx.doi.org./10.1080/1066568010340209

Hsu, S.J., \& Roth, R.E. (1998). An assessment of environmental literacy and analysis of predictors of responsible environmental behavior held by secondary teachers in the Hualien area of Taiwan. Environmental Education Research, 4, 229-246. http://dx.doi.org/1350462980040301

Kanatsouli, M. (2005). Ecology and Children’s Literature, In: A.D. Georgopoulos (Ed.), Environmental Education: the new Culture which arise, pp. 535-549. Thessaloniki: University Studio Press. 
Lesky, A. (1964). A history of Greek Literature [Translated by J. Willis and C. De Heer]. Indianapolis/Cambridge: Hackett Publishing Company.

Mc Knight, D.M. (2010). Overcoming ecophobia: fostering environmental empathy through narrative in children's science literature. Frontiers in Ecology and the Environment, 8(6), 10-15.

Munn, T., Mooney, H.A., \& Canadell, J.P. (Eds) (2001). Encyclopedia of Global Environmental Change, 2, The Earth System: Biological and Ecological Dimensions of Global Environmental Change. Chichester and New York: Wiley.

O’ Brien, K., \& Stoner, D.K. (1987). Increasing environmental awareness through children's literature. The Reading Teacher, 41, 14-19.

Palmer, J. (1998). Environmental Education for the $21^{\text {st }}$ Century. London: Routledge.

Papanoutsos, E. (1969). Aesthetics. Athens: Private Publication.

Pierce, K. M., \& Short, K.G. (1994). Environmental issues and actions. The Reading Teacher, 47, 328-335.

Skanavis, K. (2004). Environment and Society. Athens: Kaleidoskopio.

Sobel, D. (1996) Beyond ecophobia: reclaiming the heart in nature education. Great Barrington: The Orion Society and the Myrin Institute.

Tamoutseli, K. (2011). Supplementary Notes for the lesson of Environmental Education. [Online] Avaliable: http://users.auth.gr/ktam/teaching\%20strategies.htm (August 22, 2011).

Tanner, T. (1980). Significant life experiences. Journal of Environmental Education, 11, 399- 417.

Theocritus. (2003). Idylls [Translated by A. Verity, Introduction and Notes by R. Hunter]. Oxford: Oxford University Press.

Tsekos, C.A., \& Matthopoulos, D.P. (2009). Ethics, Science and the Environment: the need for a new environmental worldview. International Journal of Environmental Studies, 66(6), 679-687. http://10.1080/00207230903028326

Walbank, W.F. (1981). The Hellenistic World. New Jersey: Humanities Press. 